\title{
Klasik Türk Şiiri Terminolojisini Belâgat Çerçevesinde Anlamlandırma
}

\section{Üzeyir ASLAN 1}

\author{
$\ddot{O} z$
}

\begin{abstract}
Şair tezkireleri klasik Türk edebiyatının en önemli biyografi kaynaklarıdır. Türkçe yazılmış en eski tezkire Ali Şîr Nevâyı̂’nin Mecâlisü’n-Nefầis'ỉdir. Ondan sonra kaleme alınan Sehî Bey’in Heşt Bihiştı Nevâyı̂’nin eserini örnek alır. 15. yy.dan 19. yy.a kadar klasik tarzda tezkireler yazllmaya devam etmiştir. Arap ve Fars edebiyatındakiler de dahil olmak üzere bu eserlerde ortak terminoloji kullanılmaktadır. Latîfi Tezkiresi örneğinden hareketle bu terminolojinin şimdilik bir kısmının, klasik edebiyatın retoriğini oluşturan fesâhat ve belâgat kuralları çerçevesinde hangi anlamda kullanılmış olabileceğini inceledik. Latîfi Tezkiresỉnde geçen kavramlardan bazıları şunlardır: selîs, selâset, revân, latîf, letâfet, hoş, nâzük, rakîk, lezzet, güşâde, vâzıh, rûşen, lâyıh, metîn, ma’mûr, muhkem, râsı, garâbet, vahşiyyât, hâyîde, yâve, gilzet, sâde, sathî, pâk, sâf, hemvâr, muhayyel, rengîn, tasannu', musanna', tetebbu', tercüme, taklîd. Bu kavramlardan selîs, revân (akıcllık); latîf, hoş, nâzük, rakîk, lezzet (tatllık); güşâde, vâzıh, rûşen, lâylh (açıllık); metîn, ma’mûr, muhkem, râsıh (sağlamlık); garâbet, vahşî (alışılmışın dışında kullanım); hâyîde, yâve, gılzet (bayağılık) fesâhatle ilgilidir. Sâde, sathî, pâk, hemvâr (me'ânî); muhayyel, rengîn, zîbâ (beyân); masnû', san'at, tasannu', musanna' (bedî') ise belâgatle ilgilidir. Bu kavramlar doğrudan şiiri niteler. Tetebbu', tercüme, taklîd ise şiirin oluşum aşamasını ifade eder.
\end{abstract}

Anahtar kelimeler: Tenkit, terim, fesahat, belâgat, Latîfî.

\section{Give To Meaning The Classical Turkish Poetry Terms of Criticism Within The Framework of Rhetoric}

\begin{abstract}
Poet tazkiras are very important biography books for Turkis classical poetry. The first tazkira written in Turkish is Alī S̄ì Nevayī (1441-1501)'s Mecālisu'n-Nefäis. This is source book for poets of Middle Asia lived in 15th century and before. Secondly Hesht Behisht written by Sehī Beg in 16th century in Ottoman area. In the period of $15^{\text {th }}$ century and 19 th century tazkiras continued written with classical style and were used common terminology in them. I research a few of this terms in type of Latifi's Tazkira: selis, selaset, revan, latif, letafet, hoş, nazük, rakik, lezzet, güşade, vazih, ruşen, layih, metin, ma'mur, muhkem, rasih, garabet, vahşiyyat, hayide, yave, glzet, sade, sathi, pak, saf, hemvar, muhayyel, rengin, tasannu, musanna, tetebbu, tercüme, taklid. It seems to me that these signify fesahat (eloquence) such as selis, selaset, revan, latif, letafet, hoş, nazük, rakik, lezzet, güşade, vazih, ruşen, layih, metin and belagat (rhetoric) like muhayyel, rengin, tasannu, musanna. Some of them point out phase of poem writing, for instance: tetebbu, tercüme, taklid.
\end{abstract}

Key words: Criticism, term, eloquence, rhetoric, Latifi.

Prof. Dr., Marmara Üniversitesi, Fen Edebiyat Fakültesi, Türk Dili ve Edebiyatı Bölümü, uaslan@marmara.edu.tr [Makale kayit tarihi: 5.6.2018-kabul tarihi: $15 \cdot 8.2018]$ 


\section{Giriş}

Bilindiği üzere Türkçe yazılmış ilk şairler tezkiresi Ali Şîr Nevâyînnin Mecâlisü’n-Nefầis’idir. Nevâyî eserini Herat'ta Hüseyn-i Baykara'ya ithafen yazmış, tezkiresinin sekizinci meclisini de baştan sona ona ayırmıştır. Nevâyî eserinde Orta Asya'da tanınmış şairlerden söz eder. Bunların bir kısmı Arapça ve Farsçanın yanında Türkçe ile edebî eserler meydana getirmişlerdir. Türkçe eser veren şairlere dair malumatı biz aynı dönemde ve aynı coğrafyada, hatta Nevâyî Tezkiresi’nden önce yazılmış bir başka tezkireden daha öğreniyoruz: Devletşâh Tezkiresi. Devletşâh, Nevâyînnin öğrencidir ve tezkiresini Farsça kaleme almıştır. Bu eserden 13. ve 14. yüzyılda Türk dili ile şiirler yazmış Hasanoğlu ile Timur’un emirlerinden "Seyfi" mahlaslı Emîr Seyfeddin hakkında bilgi bulabiliyoruz.

Türkçe yazılmış ikinci eser, Sehî Bey'in Heşt Bihişt isimli tezkiresidir. Bu eserin mukaddimesinden anlaşıldığına göre müellif eserini Nevâyî̀yi örnek alarak meydana getirmiştir. Nevâyî tezkiresi sekiz meclisten oluştuğu gibi Sehî Bey’in tezkiresi de sekiz “cennet”ten meydana gelmektedir. Sehî Bey'den sonra Latîfî, Bağdatlı Ahdî, Âşık Çelebi, Hasan Çelebi, Beyânî, Âlî (Künhü’l-Ahbâr’nn Tezkire Kısmı), Garîbî ve Riyâzî tezkire telif etmişlerdir. Türk edebiyatında tezkire yazıcılığı 19 . ve 20. yüzyılda ansiklopedik eserlere dönüşmüş olsa da devam etmiştir. 1950'lerde yazılmış olan Nâil Tuman (18751958)'in Tuhfe-yi Nâilî'sini de klasik tezkireler arasında sayabiliriz.

Arap ve Fars edebiyatı şair tezkirelerinde olduğu gibi, ${ }^{2}$ özellikle 18. yüzylla kadar yazılmış Türkçe tezkirelerde şiir ve şair değerlendirmeleriyle ilgili ortak kavramların kullanıldığı görülmektedir. Aslında bu kavramların Arap, Fars ve Türk edebiyatında ortak edebî tenkit terminolojisini meydana getirdiğini söyleyebiliriz. ${ }^{3}$

Biz yalnız şiir değerlendirmelerinde kullanılan kavramları Latîfi Tezkiresi örneğinde ele alarak bunların şimdilik bir kısmının neye karşılık gelebileceği hususunda fikirlerimizi serdedeceğiz.

\section{2. Şiir Tenkidiyle İlgili Kavramlar}

Latîfi Tezkiresi (Canım 2000) incelendiğinde değerlendirilen konuların genel olarak şiir, nazım tür ve şekilleri, üslûp, söz ve anlam olduğu görülmektedir. Bunlarla ilgili kavramlar şu şekilde sıralanabilir:

genel olarak: eş’âr, şi’r, güftâr, nazm, metn, tahrîr

Latîfî, Ahmedî-yi Rûmî hakkında “... eş’ârı hayâlât u sanâyi’den ‘ârîdür.” (168), Emrî Çelebi hakkında “... şi’ri dâire-yi sûz u güdâzdan bîrûndur.” (179), Muhibbî hakkında "... rengîn güftarı vardur.” (152), Ahmedî hakkında “... nazmı sâdedür.” (164), Ahmed Paşa hakkında "... ebyât-ı pür-nükâtı elfâz u me’ânîde metn-i metîn gibi muhkem...” (155), Âhî hakkında “... tahrîr ü ta’bîri rûşen ü selîs...” (185) demektedir.

nazım tür ve şekilleri: hamse, dâstân, kasâid, kasîde, müseddes, gazel, kıt’a, târîh, ebyât, buyût, rubâî, beyt, metâli', matla', ferd

\footnotetext{
${ }^{2}$ Arap edebiyatında yazılan ilk ve en önemli tezkireler el-Cumâhî’nin Tabakâtü’ş-Şu'arâ'sı ve İbn Kuteybe'nin Kitâbu'ş-Şi’r ve'şŞu'arâ'sıdır. Fars edebiyatında ise Nizâmî-yi Arûzînin Çehâr Makâle'si ile Avfi’nin Lübâbü'l-Elbâb’ ilk eserlerdir; bk. Çetindağ 2010: 13-18, 23-31.

3 Açıkgöz 2000: 149-160. Konuyla alakalı şu çalışmalara da bakılabilir: Tolasa 1983, Kılıç 1998, Çetindağ 2010.
} 
Latîfi Tezkiresinde; Çâkerî Bey hakkında “... şehnâme ve hamse tetebbu' eder.” (207), Cafer Çelebi hakkında "... Hevesnâme nâm bir dâstân-ı dilsitânı vardur.” (209), Ahmed Paşa hakkında "... üslûb-ı kasâidi hod icmâ' u ittifâk üzre müsellemdür.” (155), Emîrî hakkında “... bu bir kaç ebyât-ı simât... kasîde-yi muhayyellerinüñ ebyâtındandur.” (180), Habîbî hakkında “... bu müseddes-i musanna’ı bir şâirüñ müsemmenine ve muhammesine benzemez." (222), Bedî’î hakkında “... terceme vü tırâş vaktuhâ gazel ü kasîde derdi.” (189), Sun’î-yi Kadîm hakkında “... zebân-ı Türkîde dahı garrâ gazelleri ve zîbâ kıt'aları ve latîf târihleri vardur." (359), Sa'dî Çelebi Efendi Müftî hakkında "... ferd ü rubâîden hûb ebyâtı... vardur.” (306), Sâfî hakkında “... buyût-ı ebyâtı kemâl-i metânetde muhkem...” (349), Şevkî hakkında "Bu bir kaç metâli'-i matbû'a anuñ eş'âr-ı sihr-âsârındandur." (335), Ahmed Paşa hakkında “... bu matla'-ı mümteniu'n-nazîrine nazîr olmaz...” (155) denilmektedir.

\section{söyleyiş biçimi: üslûb, edâ}

Latîfî, Ahmedî hakkında “... elfâz u edâsında çendân letâfet yokdur.” (163), Emrî Çelebi hakkında “... reng ü edâsı âşıkâne degüldür.” (179) ve Ahmed Paşa hakkında “... üslûb-ı kasâidi hod icmâ' u ittifâk üzre müsellemdür." (155) demektedir.

söz ve anlam: ta'bîr, terâkib, terkîb, kelimât, elfâz, lafz, makâlât, makâl, güftâr, söz, kelâm, suhan, me’ânî, ma’nâ, me'âl

Âhî hakkında “... tahrîr ü ta'bîri rûşen ü selîs...” (185), aynı şair hakkında “... terâkîb-i mu'akkad u 'akîme ihtiyâr etmemişdür” (185), Ahmed Paşa hakkında “... bu matla'-ı mümteniu’n-nazîrine nazîr olmaz ki terkîbinde bir lafz-ı bîgâne yokdur.” (155), Hâletî Çelebi hakkında hoşça kelimâtı... vardur.” (221), Hadîdî hakkında "... nâzük hayâl ve rengîn elfâz ile nazm edüp...” (222), Hızrî-yi Amasyavî hakkında "Mesnevî-gûy u sâde-makâl ve makâlâtında çendân hayâl yog idi." (247), Haydar Çelebi hakkında "... sâde güftârı vardur.” (240), Ezherî hakkında “... sözde reng ü tasannu’ sûretin gösterür...” (170), Hamdî Çelebi hakkında “... kelâm-ı âteş-te'sîr ü âbdârdur.” (236), Beyânî hakkında “... her sözinde bir zarâfet ve her suhanda bir san'at kasd edüp...” (197), Ahmed Paşa hakkında “... dîvânında mevcûd olan me’ânînüñ ekseri müdevvenât-ı selefden intihâbdur." (157), Ezherî hakkında "... ma'nâda sâdemakâldür.” (170), Zâtî hakkında “... netâyic-i me’âl-i kıssa çendân vâzıh u rûşen ...düşmemişdür.” (265) demektedir.

Değerlendirmelerde kullanılan, Latîfi Tezkiresi’nde gördüğümüz ve hemen hemen bütün tezkirelerde karşlaşabileceğimiz ifade ve kavramlar şunlardır:

âbdâr, âteşîn, âteş-te'sîr, bed degül, begâyet fasîh, begâyet ter, belîğ, bî-bedel, bîgâne, bî-hayâl, bikr ma'nâlar, bî-me’âyib, bî-mesâlib, bî-reng, cedîd hayâller, çâş̧î, çâşnîden bîrûn degül, çendân hayâl yok, çendân vâzıh, dâ'ire-yi melâhatden bîrûn, dâire-yi sûz u güdâzdan bîrûn, dakîk te'akkul, dikkat, dil-güşâ, dil-sitân, eser-i mezeden bîrûn, fesâhat-şi'âr, garîb, garrâ, gâyetde rûşen, gayrı metrûn, güşâde, hadd-i letâfet, halâvet, halâvet yok, hâlet, hâlet-bahş, hayâl, hayâlâta makrûn, hayâlâtdan 'ârî, hayâlden 'ârî, hayâlden hâlî, hâyîd, hayl-i hayâlât, hemvâr, hoş, hoşâyende, hoşça, hûb, hüsn, ifrâz, ince tehayyül, intihâb, istimâ'a kâbil, kabûle kâbil, latîf, letâfet, letâfet yok, letâfetden 'ârî, lezîz, lezzet-i şehd, ma'mûr, mahall-i tahsîn degül, makbûl, masnû', masnû'a, matbû', me’ânîden bîrûn degül, melâhat yok, memdûh, mergûb, metîn, mu'akkad u 'akîme, mu'allak, muğlak, muhayyel, muhkem, musanna', mühezzeb, mülâyim, mümteni'u'n-nazîr, münâsib, müsellem, müstahsen, mütercem, nazîr, nâzük, nefîs, nikâtdan âzâde, nükûş-ı hayâlât, pâk, pervîn-simât, pesende kâbil, pesendîde, pür-füsûn, pür-nikât, pür-sûz, reng, rengîn, rengîn degül, rûşen, sâde, sâdece, sâde-makâl, sâf, sahîh, sakîle, sakîme, san'at, sanâyi'den 
'ârî, sathî, selâkat, selefden suhan-çîn, selîs, sırf terceme, sihr-âsâr, sihr-nümûn, sûz, sûz u şevkden bîrûn, sûznâk, şîrîn, şîînter, şütür gurbe makûlesi, tab'-1 nâsa mülâyim, tahayyülâtdan âzâde, tasannu', tazmîn, terceme, teşbîhât ü temsîlât ile bast, tetebbu', tırâş, uzûbet, vahşî, vasat makûlesi, vasat mertebesinde, yâve, zarâfet, zarâfet yok, zîbâ. Bunların bir kısmı şiiri niteler; bir kısmı ise şiire alışma, şiiri geliştirme/oluşturma sürecini ifade eder.

\section{1. Şiirin niteliği ile ilgili kavramlar}

Yukarıdaki kavramlar daha önce hazırlanmış başka çalışmalarda da zikredilmiş, bunların sözlük anlamları verilmiş ancak edebî kavram olarak neye karşılık gelebileceği üzerinde durulmamıştır. Biz bu kavramların bir kısmının belâgat çerçevesinde değerlendirilebileceğini düşünüyoruz. Bunun için öncelikle belâgatın ilk aşaması olan fesâhatin, sonra da belâgatin nasıl tanımlandığına bakalım.

\subsection{1. fesâhatın tanımı}

Fesâhat "Kelimelerin söylenişinin ve dinlenmesinin tatlı ve manasının açı olması, yani telaffuz edilirken anlamının zihinde hemen çağrışım yapmasıdır.” şeklinde tanımlanmaktadır. Fasih kelimeler dil kurallarına uygun olan, şair ve yazarların daima kullandıkları kelimelerdir. Bunlar dile ağır, kulağa kötü gelmez; anlamak için sözlüğe ihtiyaç duyurmaz ve zihni yormaz (Gümüşkılıç 2016: 47).

Fesâhat için kelimeye ve kelimelerden oluşan kelâma (söze) bakmak gerekir. Kelimenin fesâhati tenâfüri hurûftan yani söyleyiş zorluğundan, garâbetden yani alışılmışın dışında kullanımdan ve kıyâsa muhalefetten yani dil bilgisi kurallarına ve yazarların kullanım biçimlerine aykırılıktan uzak olması ile mümkün olur (Gümüşkılıç 2016: 48-49).4

Kelâmın (sözün) fesâhati ise tenâfür-i kelimâttan yani kelimeler yan yana geldiğinde söyleyiş zorluğunun ortaya çıkmasından, za'f-ı te'lîften yani söz birliğinin dil bilgisi kurallarına ve yazarların kullanımına aykırı olmasından, ta'kîdden yani mana kapalılığından, kesret-i tekrârdan yani kelimelerin çok sık tekrar etmesinden ve tetâbu'-ı izâfâttan yani üçten fazla kelimenin bir araya gelerek tamlama meydana getirmesinden uzak olması ile mümkündür (Gümüşkılıç 2016: 50-57).5

Latîfi Tezkiresi’nde yukarıdaki izahatla örtüşen terminolojiye bakalım:

\section{a) akıcılık= selîs/selâset}

Tanımına göre fesâhatin ilk unsuru kelimelerin söylenişinin kolay olmasıdır. Latîfi Tezkiresỉnde "söyleyiş kolaylı̆̆ı" ile ilgili olarak "selîs/selâset" kavramı geçer. Ahmed Cevdet Paşa selâseti "Sözün dilde kolaylık ve rahatlıkla akışıdır.” şeklinde tanımlamaktadır (Gümüşkılıç 2016: 58). Latîfî, Derûnî hakkında şöyle söylüyor: “dedügi ebyâtı muhayyel ü selîs ve musanna' u nefîs derdi.” (257)

\section{b) tatlılık= latîf/letâfet vd.}

Fesâhatin bir diğer unsuru kelâmın (sözün) dinlenmesinin tatlı olmasıdır. A. Cevdet Paşa kelâm-ı latîfi şöyle tanımlıyor: "Elfâz-ı rakîkadan meydana gelen, mizaca, huya ferahlık veren manayı içeren bir sözdür." (Gümüşkılıç 2016: 60) Elfâz-ı rakîka ise "latîf, hoş, nâzik, mülâyim (yumuşak) kelimelerdir; zülf "saç”, semen-bû “yasemin kokulu”, serv-i nâz "naz servisi”, mâh-sîmâ "ay yüzlü” gibi (Gümüşkllıç

4 Ayrıca bk. Kılıç 2007: 21-22, Özdoğan vd. 2011: 47.
5 Ayrıca bk. Kılıç 2007: 22-24, Özdoğan vd. 2011: 47. 
2016: 58), yani daha çok aşk, sevgili ve âşıkla ilgili kelimelerdir. Latîf ile anlam yakınlığı olan kavramlar şunlardır:

latîf $(165,359)$, letâfet $(163,164,232,238)$, hoş (332), hoşça (211, 295), hoş-âyende (147, 186, 189, 197, 220, 221, 241, 265, 295), nâzük (147, 152, 165, 186, 220, 222, 232, 269, 270, 308), mülâyim (167, 241), istimâ'a kâbil (270, 278), dil-güşâ (182, 208, 270). Şu kavramlar da dahil edilebilir: 'uzûbet (177, 239, 314, 351), lezîz (185), lezzet (336), şîrîn (177, 182, 228, 269, 313), şîrînter (347), halâvet (164, 355), zarâfet (197), çâşnî $(296,355)$, çâşnîden bîrûn değül (252). Biz bu kavramlardan herhangi biriyle karşılaştığımızda fesahatle bağlantılı olarak kelâmın tatlılığının kasdedildiğini düşünebiliriz.

Latîfî Ahmed-i Dâî hakkında “... elfâz u edâsı îcâz u ihtisârda nâzük ü latîf olmışdur.” (165), Sun'î-yi Kadîm hakkında "... zebân-ı Türkîde dahı... latîf târîhleri vardur.” (359), Şemsî-yi Dervîş hakkında "... vâkı' olan münâzarât-ı murgânı hoş ebyât ... ile bast etmişdür.” (332), Muhibbî Sultan Süleyman hakkında “... Türkî hûb-eş’ârı ve nâzük güftârı vardur.” (152) demektedir.

zit kavramlar: eser-i mezeden bîrûn (164), halâvet yok (169).

\section{c) açıklık= güşâde vd.}

güşâde (172, 197, 241, 357), vâzıh (265), rûşen (185, 265), lâyıh (157).

Latîfi, Üsküplü İshak hakkında “... ekser-i eş’ârı... güşâde...” (172), Zâtî’nin Şem’u Pervâne'si hakkında “... çendân vâzıh u rûşen ... düşmemişdür.” (265), Âhî hakkında “... tahrîr ü ta’bîrî rûşen...” (185) diyor.

ztt kavramlar: muğlak (224), muğallak (224), mu'akkad, 'akîme.

\section{ç) uyumluluk, sağlamlık= metîn}

A. Cevdet Paşa'nın verdiği bilgiye göre Arap belagatçileri fasîh kelimeleri ikiye ayırmışlardır: 1- elfâz-ı cezele yani kalın ve ağır sözler; celâdet "cesaret, yiğitlik", hitâbet "etkili söz söyleme", kazâ/iktizâ "gereklilik”, tî̆ "kılıç”, gadr "haksızlık, acımasızlık” gibi. 2- elfâz-ı rakîka yani latîf, hoş, nazik, yumuşak kelimeler (Gümüşkılıç 2016: 58); yukarıda bahsedildi.

Kelâm-ı metîn elfâz-ı cezeleden oluşan sözdür. Yine bir kalıptan çıkmış gibi kelimelerin birbirine uyduğu söze de denir (Gümüşkılıç 2016: 59).

Latîfi Tezkiresỉnde metîn kavramı geçer. Şeyhzâde Mevlânâ Hamdî Çelebi hakkında “... her beyti beyti ma'mûr gibi menba'-1 metîndür...” (235), Sun’î Bey hakkında “... ammâ şi’ri çendân nâzük ü rengîn ve musanna' u metîn degüldür." (361)

Şunları da ekleyebiliriz: ma’mûr $(198,285,349)$, muhkem $(155,349)$.

\section{d) alışılmışın dışında kullanım = garâbet, vahşiyyât}

A. Cevdet Paşa, fesâhati bozan bir unsur olarak garâbeti, sözde alışılmışın dışında kelimelerin kullanılması olarak tanımlamakta ve şu örneği vermektedir: Farsça "ateş" kelimesi dilimizde yaygın olarak kullanılır. Aynı kelimenin Arapçası "nâr"dır, Türkçesi ise "od” kelimesidir. Kelimenin Türkçe 
olanı bugün tamamiyle terk edilmiştir. Bundan dolayı "od” kelimesinde garâbet vardır (Gümüşkılıç 2016: 48).

Latîfî, Şeyhî ve Husrev ü Şîrîn'inden bahsederken şöyle diyor: "Esnâ-yı terkîb-i nazmında kavm-i kadîmüñ Oğuzâne vü kûhâne ba'zı âdât u 'ibârâtı düşmişdür ki her biri elfâz-ı garîbeden ve 'ibârât-ı vahşiyyeden addolunur." (339).

\section{e) bayağılık= hâyîde, yâve, gılzet}

Ali Nazîmâ (1861-1935) belîğ sözlerin fasih olması şartından hareketle kelâmın belâgatinin şunlara bağlı olduğunu söylüyor -bunların bir kısmı yukarıda zikredilmişti- : 1- Garîb yani kullanımda olmayan kelimeler bulunmamalı, 2- Ayaktakımının, aşağı tabakanın kullandığı kelimelere yer verilmemeli, 3gereksiz yere ilmî kavramlar kullanılmamalı, 4- selâset, yani akıcılık olmalı, 5- cezâlet olmalı, yani harp ve savaşla ilişkili olarak tehdit gerektiren yerlerde söylenilecek sözün be, te, cim, dal, hl, sad, dad, tı, zl, ayın, kaf, kef harflerini sıklıkla içeriyor olması gerekir. 6- Letâfet olmalıdır, yani söz söylenirken ortaya çıkan sesler nazik ve mülâyim olmalıdır (Zülfe 2012: 23-24). Ali Nazîmâ'nın tarifinde yer alan ikinci maddenin Latîfi Tezkiresi’nde geçen hâyîde, yâve, gllzet "kaba, sert" kelimeleri ile örtüştüğünü söyleyebiliriz. Latîfî:

Ahmedî hakkında “... ammâ bir vechile şi’ri yâve ve nazm-ı sâdedür..” (164), Şâhidî-yi Edirnevî hakkında “... eş’ârında sâde ve hâyîde ma’nâları çokdur.” (319), Tâliî hakkında “... terkîb-i nazmı gılzet ü sıkletden mu’arrâ...”' (372) demektedir.

\subsection{2. belâgatın tanımı}

A. Cevdet Paşa belâgat ile ilgili şunları söyler: Sözün belâgatı, duruma uygunluktur yani kelimenin makama uygun olan şekliyle açıklanması ve düzenlenmesidir. Ancak mutlaka fesâhati gerektirir. Fesâhat bulunmayan sözde belâgat de yoktur. Yazar önce fasîh kelimeleri seçer ve onları birbirine uyacak şekilde dizer. Bu fesahat aşamasıdır. Sonra da duruma uygun olarak yani bir özelliği göz önünde tutarak gerekli anlamı ifade eder. Bu da belâgat aşamasıdır (Gümüşkılıç 2016: 61).

Belâgat üçe ayrılır: meânî, beyân, bedî’. Sözü gereğine uygun söyleme meânî’nin konusudur. Buna göre asll belâgati gösteren me'ânîdir. Sade ve düz bir şekilde duruma uygun olarak söylenen söz belîğ olur. Sözde teşbih, mecaz ve kinaye bulunursa bunların da hakkıyla gösterilmesi gerekir; bu beyân ile bilinir. Sâde sözlerin beyânla ilgisi yoktur. Bedî’ ise lafza ve manaya ait süsleri/sanatları konu edinir (Gümüşkllıç 2016: 181).

Buna göre me’ânî sözün gerçek anlamıyla duruma uygun söylenmesini, beyân mecaz anlamını, bedî’ ise sözü süsleyen sanatları konu edinmektedir, diyebiliriz.

A. Cevdet Paşa'ya göre sözün asıl güzelliği belâgattedir. Sözün kalitesinin ve öneminin artması belâgat iledir. Belâgatin alt bölümlerinden bedî̀in konusu olan lafza (söze) ait seci', cinas gibi süsleme sanatları ise söze suni bir güzellik katar (Gümüşkılıç 2016: 64).

Belâgat, sözü ifade şekillerinden, bunları yerine getirme yollarından ve sözün güzel yönlerinden bahsettiği için dilbilimin konusuna girer (Gümüşkılıç 2016: 82).

Tâhirü'l-Mevlevî, Muallim Nâcî’nin Belâgat hakkındaki düşüncesini şöyle aktarıyor: 
“Muallim Nâcî Efendi merhum: 'Fenn-i Belâgat meânî, beyân, bedî’ namlariyle üç kısma ayrilır. Bunlar da birer fen itibar olunur. Şu üç meseleyi nazar-ı dikkate alalım: 1- Kelâmın muktezâ-yı hâle tatbiki, 2Bir mananın yek diğerinden daha vâzı birkaç suretle ifadesi, 3- Mutabakatı, vuzuhu yolunda olan sözün tezyini. İşte bunlardan birincisi fenn-i meânî ile, ikincisi fenn-i beyân ile, üçüncüsü fenn-i bedî’ ile bilinir. Ehemmiyetleri bu tertibe göredir.” (Kürkçüoğlu 1973: 26)

Yukarıda belâgatle ilgili zikredilen fikirlerden hareket edersek;

\section{a) me’ânî ile ilgili olarak;}

\section{sadelik= sâde vd .}

sâde (164, 172, 240, 241, 247, 250, 356, 357), sâde-makâl (170, 325), sathî (240, 250, 356), pâk (311, 333), hemvâr "düz" (236).

Latîfî; Hayretî hakkında “... tab'-ı nâsa mülâyim eş’ârı ... âşıkâne ve sâde güftârı vardur.” (241), Haydar Çelebi hakkında "... eş’ârı hayâlden ârî ve sathî vü sâde güftârı vardur.” (240), Şem’î hakkında "... elfâz u edâsı dahı gâyetde rûşen ü pâk...” (333), Hamdî Çelebi hakkında “... nazmı selîs ü hemvâr...” (236) der.

\section{b) beyân ile ilgili olarak;}

\section{hayâlîlik= muhayyel, rengîn, zîbâ, mühezzeb}

A. Cevdet Paşa'ya göre muhayyelât yani hayâller, tasavvurlar ve vehimler teşbih, mecaz ve kinaye türünden olduğu için beyânın konusuna girer (Gümüşkılıç 2016: 80). Kaya Bilgegil, tehayyüle bağlı sanatlar olarak teşhis, intak, hüsn-i ta'lil ve mübâlağayı da sayar (1989: 209-224). Buna göre hayâlîlikle bağlantılı sanatlar olarak teşbih, mecaz, kinaye, teşhis, intak, hüsn-i ta'lil ve mübâlağa sayılabilir.

Latîfî, Hayâlî Çelebi hakkında “... hoş-âyende ve muhayyel eş’âr-ı sihr-nümûnı vardur.” (253), Şâmî hakkında “... eş’ârında ol kadar reng ü san'at ve hayâl ü dikkat yokdur. Terkîb-i şi’ri nazm-ı sâde makûlesidür.” (316), Harîmî hakkında “... nâzük beyânı vardur.” (147) diyor.

Ahmed Hamdî, “... 'ibâre ziyâde mazbût ve keskin ve ziyâde müzeyyen ü rengîn kılınmak içün teşbîh ü isti’âre ve mecâz u kinâye tarîkıyle îrâd olunur ki bizi bu tarz-ı muhayyel üzere kelâm inşâsına muktedir etmege mütekeffil 'ilm 'ilm-i beyândır." (Kılıç 2007: 20) der. Buna göre müzeyyen "süslü”, rengîn "renkli" kavramları da beyân ilmi ile alâkalıdır. Latîfí:

Âfitâbî hakkında “... rengîn eş’âr ile müretteb dîvânı... vardur.” (177), Şükrî-yi Sinobî hakkında “... şi'ri zîbâ ve kasîdede kasd-ı garrâsı var idi.” (323) demektedir.

zit kavramlar: çendân hayâl yok (247), tehayyülâtdan âzâde (269), bî-hayâl (325). hayâlâtdan 'ârî, hayâlden 'ârî, hayâlden hâlî, bî-reng

\section{c) bedî' ile ilgili olarak}

\section{sanatlı = san'at, tasannu', musanna'}

A. Cevdet Paşa, Belâgat'ın bir dalı olan Bedîin lafza ve manaya ait süsleri/sanatları konu edindiğini belirtmektedir (Gümüşkılıç 2016: 181). 
san'at (197), tasannu' (170), musanna' $(361,370)$

Latîfî, Beyânî hakkında “... her sözde bir zarâfet ve her suhanda bir san’at kasd edüp...” (197), Ezherî hakkında “... gerçi sözde reng ü tasannu' sûretin gösterür...” (170), Sun’î Beg hakkında “... ammâ şi’ri çendân nâzük ü rengîn ve musanna' u metîn degüldür.” (361) diyor.

zıt kavramlar: sanâyi'den 'ârî (168), tekellüf[lü] (184), sıklet (372)

Fesahat ve belagatla ilgili olduğunu düşündüğümüz edebî kavramlar aşağıdaki tabloda birlikte gösterilmiştir:

Tablo 1:

\begin{tabular}{|c|c|c|c|}
\hline \multicolumn{2}{|r|}{ Fesâhat } & \multicolumn{2}{|r|}{ Belâgat } \\
\hline Akıcılık & selîs, revân & Meânî & $\begin{array}{l}\text { sâde, sâde-makâl, sathî, pâk, sâf, } \\
\text { hemvâr "düz" } \\
\text { zit kavramlar: sakîle, sakîme }\end{array}$ \\
\hline Tatlılık & $\begin{array}{l}\text { latîf, letâfet, hoş, hoșça, nâzük, rakîk, } \\
\text { mülâyim, hoș-âyende, istimâ'a kâbil, } \\
\text { dil-güşâ, 'uzûbet, lezîz, lezzet, ŝîîn, } \\
\text { şîrînter, halâvet, zarîf, zarâfet, çâşnî, } \\
\text { çâşnîden bîrûn değül } \\
\text { zut kavramlar: eser-i mezeden } \\
\text { bîrûn, halâvet yok }\end{array}$ & Beyân & $\begin{array}{l}\text { muhayyel, hayâl, nâzük-beyân, rakîk- } \\
\text { beyân, sîrîn-beyân, beyân-1 melîh, ince } \\
\text { tahayyül, reng, rengîn, mühezzeb, zîbâ, } \\
\text { teşbîhât ü temsîlât ile bast, cedîd } \\
\text { hayâller } \\
\text { zit kavramlar: cendân hayâl yok, } \\
\text { tehayyülâtdan âaâde, bî-hayâl, } \\
\text { hayâlâtdan 'ârî̀, hayâlden 'ârî, hayâlden } \\
\text { hâlî, bî-reng }\end{array}$ \\
\hline Açıklık & $\begin{array}{l}\text { güş̧âde, vâzıh, rûşen, lâylh. zut } \\
\text { kavramlar: muğlak, muğallak, } \\
\text { mu'akkad, 'akîme }\end{array}$ & bedî' & $\begin{array}{l}\text { masnû', masnû'a, san'at, tasannu' } \\
\text { zit kavramlar: sanâyi'den 'ârî, } \\
\text { tekellüf[lü], sıklet }\end{array}$ \\
\hline $\begin{array}{l}\text { Uyumluluk, } \\
\text { Sağlamlık }\end{array}$ & metîn, ma'mûr, muhkem, râsih & & \\
\hline $\begin{array}{l}\text { Alışılmışın } \\
\text { dişında } \\
\text { kullanım }\end{array}$ & garîb, garâbet, vahşî & & \\
\hline Bayağılık & hâyîde, yâve, glzet & & \\
\hline $\begin{array}{l}\text { Genel } \\
\text { İfadeler }\end{array}$ & $\begin{array}{l}\text { begâyet fasîh, fesâhat-şi'âr, matbû' } \\
\text { "kolay, güzel, tatll" }\end{array}$ & $\begin{array}{l}\text { Genel } \\
\text { Ifadeler }\end{array}$ & belî̆g, âbdâr, nefîs, sihr-nümûn \\
\hline
\end{tabular}

\section{Örnek Çözümlemeler:}

Hayâlî Çelebi hakkında “... hoş-âyende [= fasih] ve muhayyel [= beyâna ait sanatları içeren] eş’âr-ı sihrnümûnı [= fasih ve beliğ $]$ vardur.” (253)

Şâmî hakkında “... eş’ârında ol kadar reng [= beyâna ait sanatlar] ü san’at [= bedî’e ait sanatlar] ve hayâl [= beyâna ait] ü dikkat yokdur. Terkîb-i şi’ri nazm-ı sâde [= me’ânîye ait] makûlesidür.” (316) 
Harîmî hakkında “... nâzük-beyânı [= hayalleri] vardur.”

Ziyâyî hakkında: "Rengîn [= beyâna ait; mecazlı, kinayeli, teşbihli] elfâz u edâ ve hayâlât-ı dakîka [= beyânâ ait] ile Süleymân Han nâmına hikâyet-i Yûsuf u Züleyhâsı ve kabûle kâbil ebyâtıla muhayyel [= beyâna ait] ü musanna' [= bedî’e ait; söz ve anlam sanatları ile dolu] nazm-ı dil-güşâsı [= fasîh] vardur.” (371)

Tâli'î hakkında: "Elfâz u edâsı ve terkîb-i nazmı gılzet [= kabalık, fesahate aykırı] ü sıkletden [= ağırlık, bedî’e aykırı] mu'arrâ ve ibârât-ı vahşiyyeden [= kullanımdan düşmüş kelimeler, fesâhate aykırı] müberrâ pâk [= me'ânîye ait] ü selîs [= akıcı, fesâhate ait] ve hemvâr [= me'ânîye ait] u nefîsdür [= belîğ ] ve aslâ eş'ârında terceme vü tırâş ve tazmîn ü iktibâs [= tetebbu'] yokdur.” (372)

Alî Çelebi hakkında: "Mevlânâ Hüseyin el-Vầiz el-Kâş̧ifî müellefâtından Envâr-ı Süheylî nâm kitâb-1 belâgat-nisâbın [= belîğ] -ki Kelîle ve Dimne’dür- rengîn-elfâz [= beyâna ait, mecazlı, teşbihli, kinayeli vs.] u 'uzûbet-i [= fesâhatle ilgili olarak tatlı] hüsn-i edâ ve inşâ-i dil-güşâ [= fesâhatle ilgili] ile zebân-ı Fürsden lisân-ı Türkîye terceme [= tetebbu'] edüp...” [ = fasîh ve belîğ bir şekilde tetebbu' etmiş] (401).

\title{
2.2. Şiirin oluşturulması/geliştirilmesi ile ilgili kavramlar:
}

\subsection{1. tebebbu'; tercüme, tedkik, taklîd vd.}

Tetebbu' kavram olarak tercüme, tedkik ve taklîdi kapsamaktadır. Bir başka çalışmamızda (Aslan 2018: 44-64) bu kavram üzerinde durduğumuzdan burada yalnız örnek vermekle yetineceğiz. Latîfî, tezkiresinin giriş kısmında şairlerle ilgili görüşlerini ortaya koyar ve tetebbu' edenlerle ilgili şunları söyler:

\begin{abstract}
"Kısm-ı hâmis: Ve bir kısmı dahı tetebbu'-ı devâvîn etmekle üstâd nazmuñ semt-i rûşen görmekle kesb-i isti'dâd eder, üstâd nazmında bir ma'nâyı gördükde anı bir mazmûna dahı âlet-i mülâhaza düşürür ve ta'bîr ü edâda elfâz u edâsın evvelkiden evceh ü ahsen düşürür. Veyâhud tab'-ı pâk ü lutf$ı$ idrâk ile ol ma'nâdan bir ma'nâ dahı hayâl ve ol san'atdan bir san'ata dahı intikâl edüp ilbâs-ı libâsda şâhid-i ma'nâya bir yüzden dahı sûret verür. Suhan-dânlar katında bu kısım şâ'ir-i mübdi' gibi aksâm1 mezbûreden makbûl ü mergûb ve nâzım-ı muhteri' gibi memdûh u matlûbdur.” (Canım 2000: 103)
\end{abstract}

Buna göre tetebbu’ eden şairler başarılı olduklarında kabul görmüş ve makbûl sayılmıştır.

Latîfî, Şemsî-yi Kâdî hakkında “... ve şi’r demekde defter ü dîvân tetebbu’ etmezdi.” (329), Necâtî hakkında "Zîrâ mezkûra gelince sâbıku’z-zikr olanlar [Şeyhî, Ahmed Paşa, Nizâmî-yi Karamânî] şi'ri Fürs dîvânlarından tetebbu' ederlerdi.” (342) demektedir. Latîfî, ayrıca Surûrî (301), Sabâyî (351), Ârifî Hüseyin Çelebi (381), Özrî (389), Kâtibî (452), Kâzımî (456, 457), Kâmî-yi Edirnevî (459), Keşfî (464), Lâmi’î (476), Nizâmî-yi Karamânî (534), Niyâzî-yi Bursevî (551), Helâkî-yi Rûmî (570) ve Hümâmî (574) hakkında aynı kanaattedir.

Hâfız-1 Şîrâzî (öl. 1389)'nin:

Yûsuf-i gom-geşte bâz âyed be Ken'ân gam me-hor

kulbe-yi ehzân şeved rûzî golistân gam me-hor

beytiyle başlayan gazelini Ivaz Paşa Oğlu Atâyî (öl. 1437) aşağıda matla beyti verilen gazeliyle tetebbu'/tercüme etmiştir: 
bulına bir gün şeb-i hicrâna pâyân gam yeme

vaslınuy hurşidine matla' ola cân gam yeme (g. 73/1)

Nazîre mecmualarına göre Atâyî̀nin tercüme/tetebbu' gazeli İbrâhim Beg, Ulvî ve Veznedâroğlu tarafından tanzîr edilmiştir. Bu noktada Hâfız’on değil Atâyî’nin gazelinin "zemîn” şiir kabul edildiğini görüyoruz (Aslan 2016: 46).

\section{Tablo 2:}

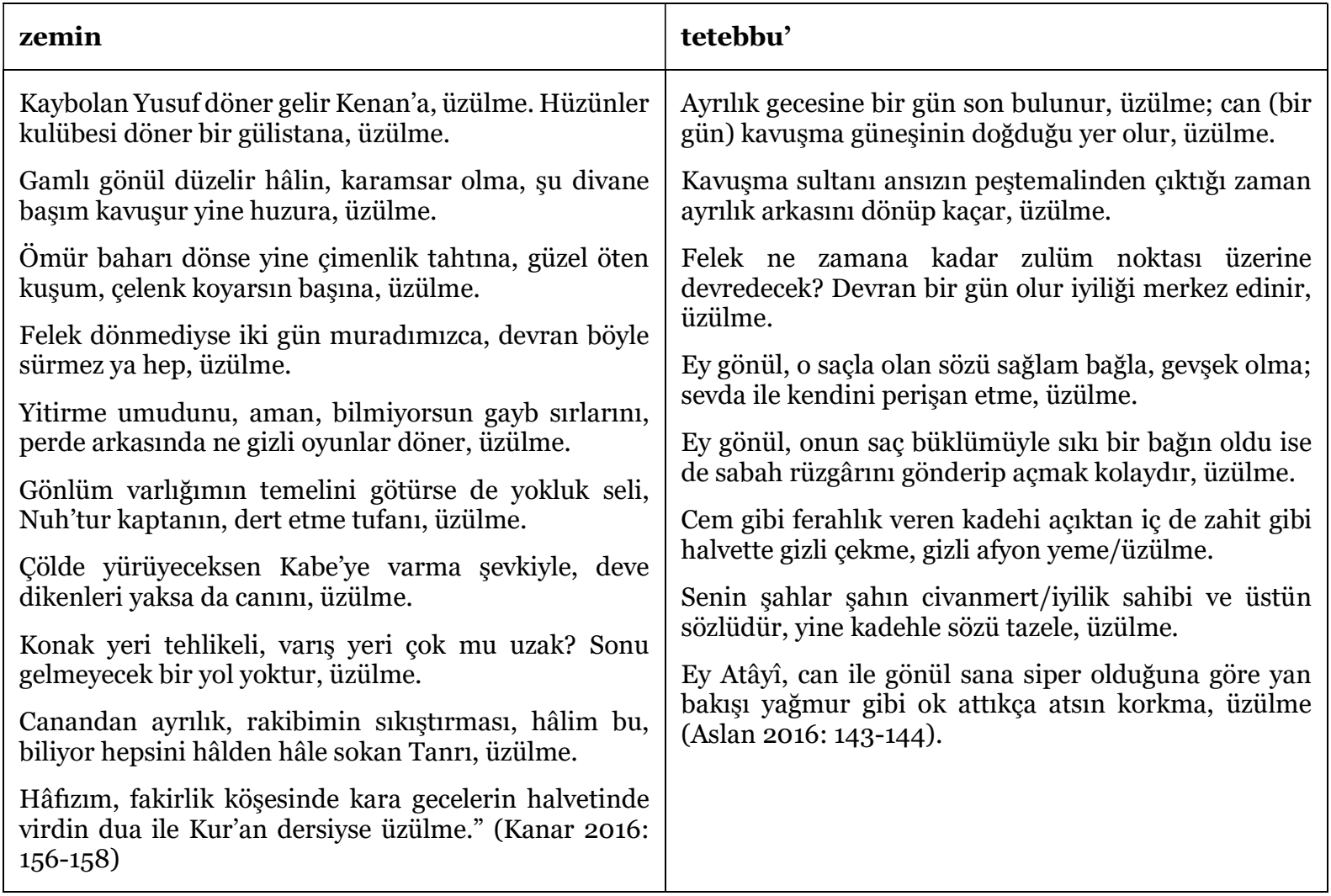

Karşılaştırılan şiirlerin vezni ve redifi aynıdır, mana açısından ise her iki şiir benzerlik göstermektedir. Bir başka örnek:

\section{Tablo 3:}

$$
\begin{aligned}
& \text { Pervîz Efendi (16. yy.) } \\
& \text { bize kâfir demiş bir ‘âlim-i dehr } \\
& \text { yalanuñ yok-durur hergiz fürûgı } \\
& \text { müsülmân diyelüm biz dahı aña } \\
& \text { durûgî-râ ne-şâyed cuz durûgî } \\
& \text { "Yalana yalandan başkası yaraşmaz.” }
\end{aligned}
$$

(Solmaz 2005: 136)

\author{
Nefî̀ (öl. 1635) \\ bize kâfir demiş müftî efendi \\ tutalum ben aña diyem müsülmân \\ varıldukda yarın rûz-ı cezâya \\ ikimüz de çıkaruz anda yalan
}

(Sihâm-ı Kazâ'dan) 
Nef'̂̀ye ait yukarıdaki kıtanın Pervîz Efendiye nazire olması bizim kanaatimize göre -diğer çalışmamızdan da hareketle- mümkün değildir, bu benzerlik tetebbu'u işaret etmektedir.

\section{Sonuç}

Şair tezkirelerinde karşılaştığımız "tenkit terminolojisi"ni oluşturan kavramların fesâhat ve belâgat çerçevesinde anlamlandırılmasının mümkün, hatta gerekli olduğu kanaatindeyiz.

\section{Kaynaklar}

Açıkgöz, N. (2000). "Klasik Türk Şiiri Tenkid Terminolojisi ve 'Âb-dâr' Örneği”. Türk Kültürü İncelemeleri Dergisi. S. 2. İstanbul. s. 149-160.

Aslan, Ü. (2016). Ivaz Paşa Oğlu (öl. 1437) ‘Atâyî Dîvânı. Kriter Yayınları. İstanbul.

Aslan, Ü. (2018). “Âşı̀ Çelebi’nin Tetebbu’ Şiirleri”. Bir Devr-i Kadîm Efendisi Prof. Dr. Tahir Üzgör’e Armağan. Ed. Ü. Asslan - H. Taş - Ö. Zülfe. Yayın Evi. Ankara. s. 44-64.

Bilgegil, K. (1989). Edebiyat Bilgi ve Teorileri (Belâgat). Enderun Yayınları. İstanbul.

Canım, R. (2000). Latîfî: Tezkiretü’ş-Şu'arâ ve Tabsıratü’n-Nuzemâ (İnceleme-Metin). hzl. Rıdvan Canım. Atatürk Kültür Merkezi Yayını. Ankara.

Çetindă̆, Y. (2010). Şiir ve Tenkit - Türk. İran ve Arap Tezkirelerinde- Kitabevi Yayınları. İstanbul.

Gümüşkılıç, M. (2016). Ahmet Cevdet Paşa: Belâgat-ı Osmâniyye. Kapı Yayınları. İstanbul.

Kanar, M. (2016). "Hafız Divanı Üzerinde Yeni Bir Çeviri Çalışması Hafız’ın Şiirlerinin Farsça Öğretimine Katkısı Üzerine Denemeler”. 28/09/2016. sa. 11: 30. http://istanbuluniversitesi.beta.dergipark.gov.tr/download/article-file/10360. s. 156-158.

Kılıç, A. (2007). Ahmed Hamdî: Belâgat-ı Lisân-ı 'Osmânî (İnceleme-Metin-Dizin). Laçin Yayınları. Kayseri.

Kılıç, F. (1998). XVII. Yüzyıl Tezkirelerinde Şair ve Eser Üzerine Değerlendirmeler. Akçağ Yayınları. Ankara.

Kürkçüoğlu, K. E. (1973). Tahir'ül-Mevlevî: Edebiyat Lügatı. Enderun Yayınları. İstanbul.

Özdoğan, M. A. Temizkan, A. Dinç, A. (2011). Yemlihazâde Mustafa Kâmil: Nazmü’l-Fünûn. Ukde Kitaplığı. Kahramanmaraş.

Solmaz, S. (2005). Ahdî ve Gülşen-i Şu'arâsı (İnceleme - Metin). Atatürk Kültür Merkezi yayını. Ankara.

Taş, H.. (2018). "Edebî Sanatların Metin Tamirine Katkısı". Bir Devr-i Kadîm Efendisi Prof. Dr. Tahir Üzgör'e Armağan. Ed. Ü. Aslan - H. Taş - Ö. Zülfe. Yayın Evi. Ankara. 620-639.

Tolasa, H. (1983). Sehî, Latîfî, Âşık Çelebi Tezkirelerine Göre 16. YY.da Edebiyat Araştırma ve Eleştirisi I. Ege Üniversitesi Edebiyat Fakültesi Yayınları. İzmir.

Zülfe, Ö. (2012). Ali Nazîmâ: Muhtıra-i Belâgat. Yedirenk. İstanbul. 